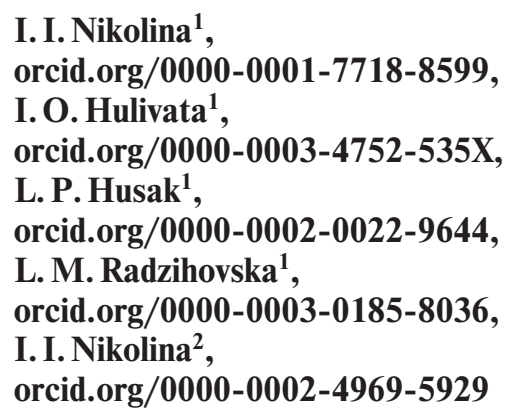

1 - Vinnytsia Institute of Trade and Economics of KNUTE, Vinnytsia, Ukraine, e-mail: nikira1205@gmail.com 2 - Vinnytsia State Pedagogical University named after Mikhail Kotsyubinsky, Vinnytsia, Ukraine

\title{
ASSESSMENT OF DIGITALIZATION OF PUBLIC MANAGEMENT AND ADMINISTRATION AT THE LEVEL OF TERRITORIAL COMMUNITIES
}

Purpose. To substantiate methodology for applying mathematical methods to the assessment of digitalization of public management and administration, approbation of the authors' model of this assessment at the level of territorial communities.

Methodology. Theoretical (analysis, synthesis, systematization, generalization) and empirical (observation, mathematical and statistical analysis, modelling, comparison) research methods are applied.

Findings. The analysis of the process of digital governance formation in Ukrainian realities and the research on conceptual approaches of global indices to the assessment of developing digital society and digital governance made it possible to develop analytical tools adapted to the specifics of digital development content at the local level. The authors prove that the assessment of digital governance will increase the reliability of the process of decision development and decision making in the sphere of management of complex multi-level socio-economic systems, providing an opportunity of assessing different strategies of digital transformation. The authors propose their own tested model in order to provide full understanding of digitalization of public management and administration at the local level. It is proved that the authors' methodology allows for a systematic analysis of the state of digitalization of public management and administration at the level of territorial communities.

Originality. The scientific novelty consists in the statement and solution of the problem of improving the methodological tools for assessing the digitalization of public management and administration at the level of territorial communities by using four indicators of the integrated index: sub-indices of service provision quality and public information access, website functionality, digital socio-political inclusion, internal electronic document management system of local self-government bodies.

Practical value. A practical example of implementation of the above-mentioned model is demonstrated in order to provide full understanding of the level of digital transformation at the local level.

Keywords: digital transformation, public management, administration, model, territorial community

Introduction. Transformational changes of modern Ukraine are conditioned by global digitalization that reflects the causal connection between the Fourth Industrial Revolution ("Industry 4.0") and the development of society ("digital society"). The scale and pace of digital transformations have become the main characteristics of economic development [1].

Digitalization is aimed at providing every citizen with equal access to services, information and knowledge on the basis of digital technologies. The introduction of digital technologies has a positive impact on the effectiveness and efficiency, quality and cost of public, community and personal activities. Digital technologies open new opportunities for socio-political inclusion of citizens.

These technologies are increasingly used in management and interaction between the state, regions and communities, as well as in communication between public authorities and residents. Openness, transparency, government accountability and citizen participation in policy making and implementation are the basis for good governance, and digital technologies ensure the accessibility and simplicity of these processes.

In order to analyse the process of implementation of the "digital" platform at the level of state/regions/territorial communities, achievement of goals and functional tasks and determination of the results of public institutions' activities on digitalization there should be conducted an assessment.

"Action plan for the implementation of the Concept of development of the digital economy and society of Ukraine for 2018-2020", approved by the Cabinet of Ministers of Ukraine,

(C) Nikolina I. I., Hulivata I. O., Husak L. P., Radzihovska L. M., Nikolina I. I., 2020 dated January 17, 2018 No. 67-p, determines the necessity of developing and substantiating indices, indicators and methods for assessing digital development of Ukraine accordingly to international development practices [1]. In "Grounds of implementation by executive authorities of the principles of state policy of digital development", approved by the Cabinet of Ministers of Ukraine, dated January 30, 2019 No. 56, there is also emphasized a necessity to adhere to such principle of digital governance as "assessment of efficiency and effectiveness" [2].

Literature review. The implementation of the trend of digital transformation of public management and administration has become the object of research of many foreign scientists in the field of public administration. Thus, in our opinion, special attention is drawn to the works of the following researchers: P. Dunleavy and H. Margetts [3], B. Corydon, V. Ganesan and M. Lundqvist [4]. UN experts measuring the E-Government Development Index [5, 6], the E-Participation Index [7] considered theoretical and practical aspects of e-government implementation, assessed the development of e-government and digital participation at the national level.

In Ukraine, the issues of digitalization of public management and administration in general, and its assessment in particular, have been investigated insufficiently, though there are works by leading domestic scientists in which the essence of e-government, its formation and development in Ukraine and worldwide are revealed, and the measuring system of development of information society and e-government is analyzed.

In the works by V. Kuibida, O. Karpenko it is substantiated that digitalization transforms management processes, qualitatively improving them, creating new digital services and innovative forms of service activities of public authorities and local self-government bodies [8,9]. 
In recent years, international organizations have been assessing the development of e-government, e-participation at the national level [5-7], a number of initiatives of civil society institutions aimed at determining the effectiveness of some individual e-government tools at the local level has been implemented [10].

However, the unresolved part of the general problem of the research is the theoretical and methodological substantiation of assessing the digital transformation of public management and administration in Ukraine at the level of territorial communities.

Purpose. The aim of the article is to scientifically and theoretically substantiate the applying of mathematical methods for assessing digitalization of public management and administration, and the main task is to analyse the existing methodology, develop and test a model of assessing of digitalization of public management and administration at the level of local communities.

Methods. Research tasks determined the use of the following methods: abstract and logical method aimed at theoretical generalization and formulation of conclusions; data collection methods applied in empirical studies; mathematical and statistical analysis of information, which made it possible to form a database of the actual state of digitalization of public management and administration in Ukraine at the level of territorial communities; expert survey which provided a comprehensive understanding of the level of digitalization of public management and administration; modelling made it possible to obtain rating values of the integrated index of digitalization of public management and administration of the UTC (united territorial community) under investigation; due to comparative analysis the comparability of assessments was ensured in the process of characterizing digitalization of public management and administration of the UTC during the period under review.

Results. The role of the state and state administration was perceived differently through history, starting with the all-encompassing Leviathan, the interpretation of the state as the centre of the world mind and creator of history in the Hegelian spirit, Weber's model of rational bureaucracy, ending with a service approach that presents the state as an organization focused on providing services to citizens, with the reformatting of the relationship between the state and citizens: from guardianship - to partnership, and a modern vision of management inclusiveness on the basis of digital standards (according to the principle of "Digital by Default").

Thus, the evolution of management model in the public sector can be represented through the dynamics of the terminological system: "public administration" $\rightarrow$ "public management" $\rightarrow$ "new public management" $\rightarrow$ "e-government" $\rightarrow$ "digital governance".

Digitalization of public management and administration (digital governance) is a form of organization of public administration focused on meeting the needs of citizens, which provides efficiency, openness and transparency of public authorities and local self-government bodies, as well as a possibility for their interaction with society, an individual or business through digital technologies if all participants of the communication have appropriate digital competencies.

In their works, V. Kuibida, and O. Karpenko monitored evolutionary changes in the paradigm of introduction of information and communication technologies in the activities of public authorities: "informatization of state administration" $\rightarrow$ "e-government" $\rightarrow$ "digitalization of public management and administration (digital governance)" [8,9].

The process of formation of digital governance in most countries is multi-vector, i.e. it is produced both "from above" - at the level of central public authorities, and "from below" - at the level of regions, territorial communities and community initiatives that generate demand for change [3]. A similar situation can be observed in Ukraine.

In Ukraine, the challenges of digitalization of public management and administration are reflected in a number of regulations of the Cabinet of Ministers of Ukraine: such orders as
"Some issues of public management reform in Ukraine", dated June 24, 2016 No. 474-p, "On approval of the Concept of eservices development in Ukraine", dated November 16, 2016 No. 918-p, "On approval of the Concept of e-government development in Ukraine", dated September 20, 2017 No. 649-p, "On approval of the action plan for the implementation of the Concept of e-services development in Ukraine for 2017-2018", dated June 14, 2017 No. 394-p and "On approval of the Concept of development of the digital economy and society of Ukraine for 2018-2020 and approval of the action plan for its implementation", dated January 17, 2018 No. 67-p; rulings "On approval of the Regulations on data sets to be disclosed in the form of open data" of October 21, 2015 No. 835, "Some issues of electronic interaction of state electronic information resources" of September 8, 2016 No. 606, "Some issues of documenting management activities", dated January 172018 No. 55, "Some issues of digital development", dated January 30, 2019 No. 56.

It should be noted that the creation of conditions for the "abrupt" development of digitalization of state governance (public management and administration) is laid down in the draft law of Ukraine "On the digital agenda of Ukraine" [11], in the order of the Cabinet of Ministers of Ukraine "On the Action plan for the implementation of the Concept of development of the digital economy and society of Ukraine for 2018-2020", dated January 17, 2018 No. 67-p [1].

On November 7, 2018, the law of Ukraine "On electronic trust services" came into force, which is aimed at reforming of the national regulatory framework in the field of qualified digital signatures through the implementation of the European Union legislation. It exercises the right to Mobile ID services - a promising digital technology that enables the growth of digital governance with mandatory socio-political inclusion and responsible participation of citizens, that is with digital participation [12].

At the level of regions and territorial communities, e-petitions, e-appeals, e-consultations and e-participatory budgets are common tools for e-democracy. O. Karpenko, O. Levchenko and S. Sakalosh prove that the use of digital democracy tools (as opposed to e-democracy) at the regional or local levels requires digital transformations, the introduction of digital technologies and the availability of appropriate digital competencies [13].

We are convinced that the synergy of promising areas of use of mobile, social, cloud technologies, data analysis technologies, Open Data, Digital Identification, Digital Government Platforms, Blockchain, Digital Workplace, Multichannel citizen engagement, Anything as a Service (XaaS), IoS, Cyber-Physical Systems, Smart Factory, Sharedservices 2.0 $[11,14-16]$ in combination with the appropriate digital competencies of public officials, citizens, stakeholders can lead to revolutionary changes in public management and administration, make it valuable, effective, reactive.

For digital governance, the communication links will be obviously bidirectional: "government $\leftrightarrow$ government", "government $\leftrightarrow$ business", "government $\leftrightarrow$ citizens", "government $\leftrightarrow$ employees".

It is apparent that the assessment of digital governance will increase the reliability of the process of development and decision-making in the management of complex multi-level socioeconomic systems, providing an opportunity to assess different strategies of digital transformation.

In our opinion, the analysis of recognized global methods for assessing the development of digital society and digital governance will be useful for developing such analytical tools that, based on the conceptual approaches of global indices, will be adapted to the specific content of development of digital Ukraine at the local level.

Thus, the level of e-government development of countries has been assessed by the United Nations Department of Economic and Social Affairs (UNDESA) since 2003 according to the EGDI (E Government Development Index), the measurement is carried out every two years with the indicators of 
193 countries being taken into account. The EGDI is a composite index made up of other sub-indices and used to measure the readiness and capacity of national administrations to use information and communication technologies to provide information services to the public, business and for the needs of the authorities themselves [5].

In a formalized way, the EGDI looks like an average weighted assessment of three normalized scores on the three most important aspects of e-government according to the UNDESA methodology [6]

$$
E G D I=1 / 3\left(O S I_{\text {normalized }}+T I I_{\text {normalized }}+H C l_{\text {normalized }}\right),
$$

where $O S I_{\text {normalized }}$ stands for the Online Services Index; TII $I_{\text {normalized }}$ - the Telecommunication Infrastructure Index; $H C I_{\text {normalized }}$ - the Human Capital Index.

The EPI (E-Participation Index) is calculated by UN experts along with the EGDI. Encouraging citizen participation in digital interaction is a cornerstone of socio-political inclusion. The tasks of the state regarding electronic participation of citizens, on the one hand, are to improve citizens' access to information and public services; on the other - to promote participation in public decision-making.

The EPI expands the aspect of the survey concerning digital governance by focusing on the use of online services for simplifying the provision of information by citizens, interaction with stakeholders and participation in decision-making. Mathematically, the EPI is calculated as the sum of three indicators: e-consulting, e-informing, e-decision making. [7].

By means of the analysed indices individual segments of digitalization of public management and administration are measured at the national level. Direct use of mathematical models of the EGDI and EPI for assessing the digitalization of public management and administration at the level of territorial communities is not possible. Changes and additions of global indices should be aimed at taking into account the diagnostics of local peculiarities of the formation and development of e-government; the creation and use of new digital tools by territorial public authorities; dependence on the available information base on digital activities of territorial communities and the interaction of digital governance entities; the aggregation of assessment indicators depending on the possibility or impossibility to quantify the results of certain areas of digitalization of public management and administration of territorial communities; the conclusions of the expert survey, etc.

In Ukraine, there is a practice of assessing the development of e-government by public organizations according to their own models:

- publicity Index of Local Self-Government of regional centres of Ukraine (Publicity Index of Local Self-Government) - annual monitoring of the level of openness, transparency and publicity of municipalities, due to the use of digital tools as well;

- monitoring of the level of implementation of e-government tools in local self-government bodies of the largest cities of Ukraine was carried out annually in five main areas: the level of information content of official Internet resources of city councils, the degree of implementation of e-participation tools in cities of Ukraine, the level of access to information that is at the disposal of local self-government bodies, the level of citizens' access to administrative services and the degree of implementation of electronic document management systems in the activities of city councils [10].

Proceeding from the conceptual approaches of the global EGDI and EPI, the results of the survey of the expert group, which included scientists in the field of public management, government and local self-government officials, representatives of public organizations, we developed a methodology and the LDGI (Local Digital Governance Index) model, adapted to the specifics of the level of territorial communities in order to provide a comprehensive understanding of the level of digitalization of public management and administration.
We started from the fact that a necessary condition for the validity of the results of diagnostic conclusions should be the substantiation of assessment criteria (digitalization indicators) selection and the reliability of indicators that will detail the results of the digital governance assessment.

In our opinion, it is expedient to choose such digitalization indicators that will represent communication links between the main entities of digital governance (Table 1) which classically are represented as interaction sectors:

- G2G ("government to government") - a sector of electronic interaction between authorities. It includes the organization of electronic document management and data exchange between government electronic registers on the basis of the principle of unification, interchangeability and compatibility;

- G2B ("government to business") - a sector of electronic interaction between public authorities and economic entities the aim of which is to support and develop business by means of ICTs through the provision of administrative and other services, business participation in the implementation of state policy and programs;

- G2C ("government to citizens") - a sector of electronic interaction between public authorities and citizens aimed at providing citizens with quality and timely public services, citizen participation in state policy making and the electoral process, the assessment and control of activities of public authorities and so on;

- G2E ("government to employees") - a sector of interaction between public authorities and public officials themselves.

The selection of the system of representative indicators (Fig. 1) of digitalization of public management and administration at the level of territorial communities is conditioned by a number of factors: availability of a regional information base; possibility or impossibility to quantify the results of certain areas of digital governance; the analysis of the characteristics of introducing digital technologies.

In a formalized way, the integrated index of digitalization of public management and administration at the level of territorial communities LDGI can be represented as a function of many variables

$$
L D G I=f\left(S_{q}, W_{f}, I_{d}, D_{e f}\right),
$$

where $S_{q}$ stands for the sub-index of quality of service provision and public information access; $W_{f}$ is the sub-index of website functionality; $I_{d}$ is the sub-index of digital socio-political inclusion; $D_{e f}$ stands for the sub-index of the system of internal electronic document management of local self-government bodies.

Table 1

Characteristics of indicators of digitalization of public management and administration

\begin{tabular}{|l|l|l|}
\hline $\begin{array}{c}\text { Interaction } \\
\text { sector }\end{array}$ & \multicolumn{1}{|c|}{ Indicators } & $\begin{array}{l}\text { Investigated characteristics of } \\
\text { indicators }\end{array}$ \\
\hline $\begin{array}{l}\text { G2C, } \\
\text { G2B }\end{array}$ & Website functionality & $\begin{array}{l}\text { Measurability of site content, } \\
\text { availability of feedback, ease of } \\
\text { access to public information, } \\
\text { interface friendliness }\end{array}$ \\
\hline $\begin{array}{l}\text { G2G, } \\
\text { G2E }\end{array}$ & $\begin{array}{l}\text { System of internal } \\
\text { electronic document } \\
\text { management of local } \\
\text { self-government bodies }\end{array}$ & $\begin{array}{l}\text { Measurability of the system of } \\
\text { internal document circulation } \\
\text { and exchange, document } \\
\text { archive, security level }\end{array}$ \\
\hline $\begin{array}{l}\text { G2E, } \\
\text { G2B }\end{array}$ & $\begin{array}{l}\text { Quality of service } \\
\text { provision and public } \\
\text { information access }\end{array}$ & $\begin{array}{l}\text { Measurability of administrative } \\
\text { services, access to public } \\
\text { information, public feedback } \\
\text { and activities of administrative } \\
\text { service centres }\end{array}$ \\
\hline $\begin{array}{l}\text { G2C, } \\
\text { G2B }\end{array}$ & $\begin{array}{l}\text { Digital socio-political } \\
\text { inclusion }\end{array}$ & $\begin{array}{l}\text { Measurability of tools that can } \\
\text { ensure constructive interaction } \\
\text { between government and the } \\
\text { public }\end{array}$ \\
\hline
\end{tabular}




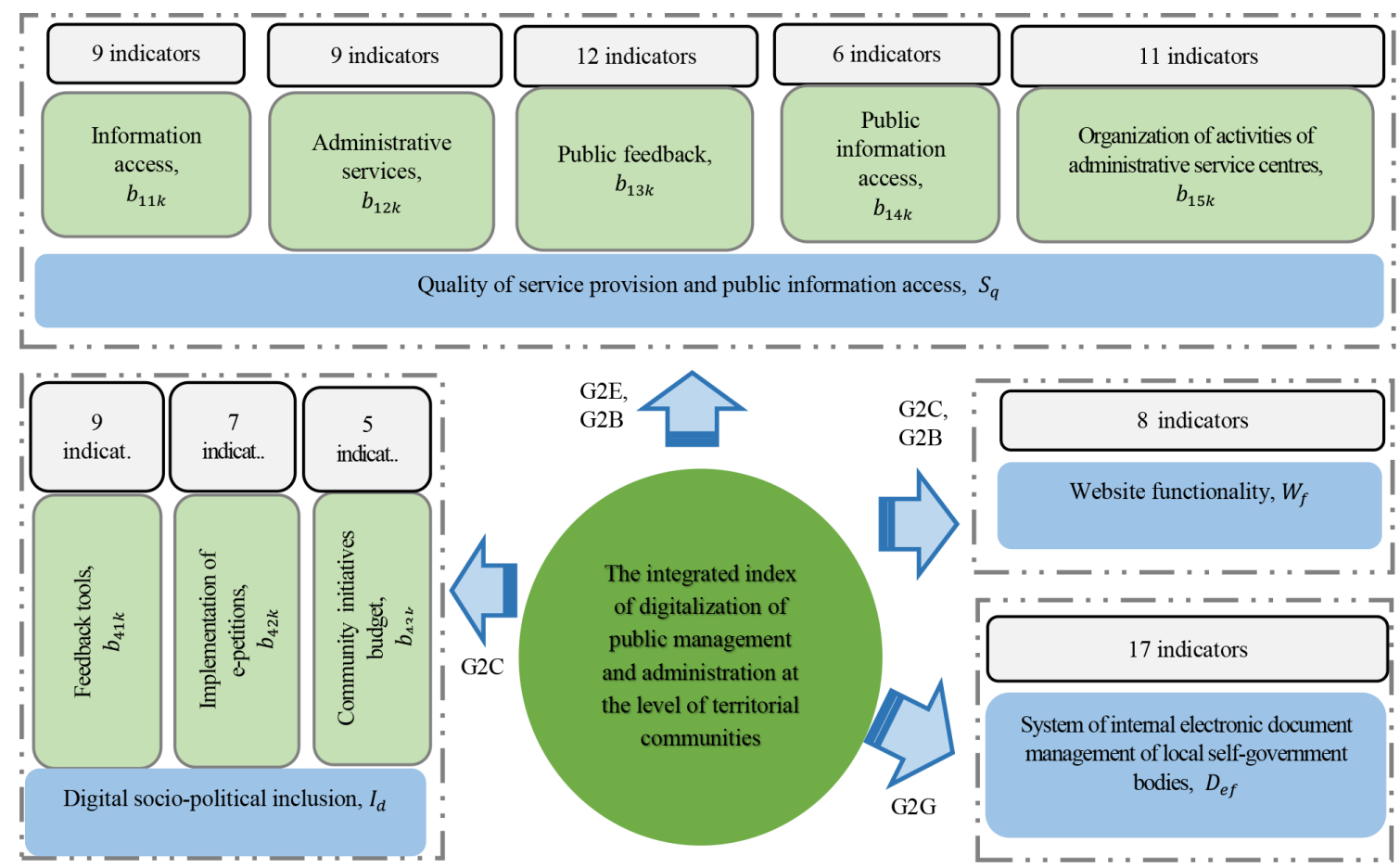

Fig. 1. Scheme of assessing digitalization of public management and administration at the level of territorial communities

We believe that the proposed system of indicators reproduces the quantitative and qualitative aspects of the development of digital governance, which complement each other and provide informative and holistic characteristics of digitalization of public management and administration at the level of territorial communities, make it possible to assess the conditions of its formation and changes.

The sub-index of quality of service provision and public information access $S_{q}$ is detailed by the following analytical indicators that are grouped into factors of influence $b_{1 j k}(k-$ sequence number of the investigated territorial community):

1) $b_{11 k}$ : information access (information on activities of the local self-government body, the city (village) mayor and his/her assistants, the list of executive bodies of the city council, their structure, location, working hours; the list of municipal enterprises, institutions of social sphere that provide services to population, medical, recreation institutions, preschool and general education institutions with indication of address, directors, telephone numbers, working hours; information on current activities (procurement plans, budget, projects, auctions, competitions, available vacancies); historical and cultural information; news and announcements of official events and meetings, and so on);

2) $b_{12 k}$ : administrative services (contact details and reception hours of administrative services centres (ASCs); the list and classification of provided administrative services, availability of information cards of administrative services; possibility to send an e-mail to the ASC for advice; possibility of submitting an application and documents for receiving administrative services / of electronic queuing via one's personal user account; possibility to monitor the status of processing of the application for administrative services; possibility to download application forms for administrative services or documents for the issuance of permits; website information about the location of places where the necessary application forms of the institution are provided to applicants, etc.);

3) $b_{13 k}$ : public feedback (availability of online reception of the head of the territorial community, available form for submitting electronic appeals; possibility to track the processing of e-appeals; statistics on citizens' appeals published on the website; carrying out of online public survey on topical issues of the life of the territorial community; the possibility to discuss draft documents, and others);
4) $b_{14 k}$ : public information access (information on a special structural unit or a person responsible to ensure access to public information; availability of public information request forms; possibility to request public information via e-mail; information on the accounting system (public information register), types of information stored by the monitor; information on the procedure for compiling, submitting a request for information, appealing against the decisions of information monitors, actions or omissions; reports on the satisfaction of requests for information);

5) $b_{15 k}$ : the assessment of organization of administrative services centres' activities (availability of reception, electronic queuing system, information electronic self-service terminals, zoning of ASC premises, ASC security system, information stands, stands with sample applications; creating conditions for people with limited physical capacities (availability of ramps, adapted information terminals, stands), notifying users on the result for administrative services provision; provision of "related" services (photocopying, banking services, and others) in ASC premises; availability of mechanisms for obtaining consumer opinion (feedback books, suggestion boxes, exit polls, etc.), and so on).

The sub-index of website functionality $W_{f}$ is represented by the following analytical indicators that are grouped in $b_{2 k}$ : availability of site search, site map, mobile version of the website, navigation menu on each page of the site, multilingual version of the site, website version for the visually impaired; the possibility to search for information by tags, return to the main page from any page of the site, and so on.

The sub-index of the system of internal electronic document management of local governments $D_{e f}$ is determined on the basis of the following analytical indicators, which are grouped in $b_{3 k}$ : availability of internal electronic document management system at the local self-government body; a number of employees (as a percentage of the total number) working with electronic document management system (EDMS); each employee working in the sphere of electronic document management has a personal access password to the data of electronic document management system and an electronic digital signature; available distributed user access to EDMS; availability of an electronic system for registration of citizens' appeals in EDMS; availability of electronic registration of incoming and outgoing documents of the electronic archive, documents of the local self-government body; scan- 
ning of incoming documents; connection of municipal enterprises and institutions of the city to electronic document management system, exchange of electronic documents with state authorities of different levels by means of EDMSs; exchange of electronic documents with other authorities with the use of a digital signature; integration of electronic document management system with other systems; training for staff on the use of EDMS; staff testing for the ability to use EDMS; electronic endorsement of regulatory documents in EDMS; integration of electronic document management system with mobile devices.

The sub-index of digital socio-political inclusion $I_{d}$ is detailed by the following analytical criteria that are grouped into the factors of influence $b_{4 j k}$ :

1) $b_{41 k}$ : feedback tools (website interactivity; a communication platform that allows for real-time communication with dispatch service (online chat), online broadcasting of council meetings (availability of a specialized section or service on the site); available mobile applications concerning the territorial community functioning, e-consulting and e-voting services; representation of local public authorities in social networks; possibility to leave a comment via social media; training for officials of public authorities and residents of the territorial community on the use of feedback tools, testing of public officials for the ability to use feedback tools);

2) $b_{42 k}$ : implementation of e-petitions (issues related to the submission of electronic petitions are recorded in the statutes of territorial communities, either regulations on electronic petitions or the order of their consideration which regulated all related procedures in more detail are approved; compliance with legislation requirements concerning the implementation of e-petitions; compliance with the recommendations on the number of votes required for consideration of the petition; available e-petitions service with a user-friendly interface, data visualization; methodological recommendations for citizens on the initiation and formulation of texts of electronic petitions; the activity level of the e-petitions system usage, and others);

3) $b_{43 k}$ : community initiatives budget (available information about the project on the city council website; open access to all submitted projects; availability of regulatory framework necessary for the holding of a competitive tender; available service for online voting for the best project; available information on the implementation of winning projects).

The analytical indicators are calculated in scores, the summed values of which form the value of influence factor $b_{i j k}$.

Consolidation of the values of each influence factor $b_{i j k}$ should be carried out taking into consideration the weights of influence $\beta_{i j}$, determined on the basis of the expert survey.

The value of indices $W_{f}, I_{d}$, at the level of territorial communities is calculated as the sum of 8 and 17 analytical indicators accordingly.

The value of indices $S_{q}, D_{e f}$ at the level of territorial communities according to the $i$-group of indicators is determined in the following way

$$
\begin{gathered}
S_{q}=\sum_{j=1}^{5} b_{1 j k} \cdot \beta_{1 j} ; \\
\sum_{j=1}^{5} \beta_{1 j}=1 ; \\
0 \leq \beta_{1 j} \leq 1 ; \\
D_{e f}=\sum_{j=1}^{3} b_{4 j k} \cdot \beta_{4 j} ; \\
\sum_{j=1}^{3} \beta_{4 j}=1 ; \\
0 \leq \beta_{4 j} \leq 1,
\end{gathered}
$$

where $\beta_{i j}$ is a weight coefficient of the $j$-indicator of the $1^{\text {st }}$ or $4^{\text {th }}$ group; $k$ stands for the number of the investigated territorial community, $(k=1, \ldots, l)$.

In order to define weight coefficients of the indicators within one group we used the method for scoring the expert review object by experts. Weight coefficients are defined on the basis of scores which are given by experts and reflect the subjective opinion of the expert concerning the influenceability, value and importance of the indicator. Scores are taken from the special assessment numeral scale.

The integrated index of the assessment of digitalization of public management and administration at the level of territorial communities $L G D I$ of the $k$-city, town, village is calculated in the following way

$$
\begin{gathered}
L G D I=S_{q^{\prime}} \cdot \lambda_{s}+W_{f} \cdot \lambda_{W}+I_{d} \cdot \lambda_{i}+D_{e f} \cdot \lambda_{d} ; \\
\lambda_{s}+\lambda_{w}+\lambda_{i}+\lambda_{d}=1, \quad 0 \leq \lambda_{s}, \lambda_{w}, \lambda_{i}, \lambda_{d} \leq 1,
\end{gathered}
$$

where $\lambda_{s}, \lambda_{w}, \lambda_{i}, \lambda_{d}$ stand for weight coefficients of the indices of quality of service provision and public information access, website functionality, digital socio-political inclusion, inner electronic document management system of local self-government bodies accordingly.

The proposed mathematical model for assessing digitalization of public management and administration at the level of territorial communities is open for logical changes and additions.

In order to test the developed methodology, digitalization of public management and administration was assessed on the example of Vinnytsia city united territorial community during 2014-2018, according to the monitoring data of the NGO "Podillia Agency for Regional Development", starting from 2014. The results of calculations are given in Table 2 .

The state of digitalization of public management and administration of Vinnytsia city united territorial community is visually presented in Fig. 2.

Ranking was carried out in order to make a rating. The $L D G I$ value has a variation interval $-(0 ; 14.64)$. The best integrated assessment of digitalization of public management and administration at the level of territorial communities is in the period when the index $L D G I$ takes a value close to " 14.64 " and the worst - in which it is close to " 0 ".

The division of groups of regions into clusters by means of rating values according to the scoring system allowed us to identify 5 clusters in which the assessment of digitalization of public management and administration at the level of territorial communities has similar values: A - highly developed territorial communities $[14.40 ; 14.64)$; B - rapidly developing territorial communities $[13.55 ; 14.40) ; \mathrm{C}$ - territorial communities of medium level of development $[12.14 ; 13.55)$; D - developing territorial communities $[10.13 ; 12.14)$; E - underdeveloped territorial communities $[0 ; 10.13)$.

In order to forecast the dynamics of the level of digitalization of public management and administration of Vinnytsia city united territorial community, a graphical method was

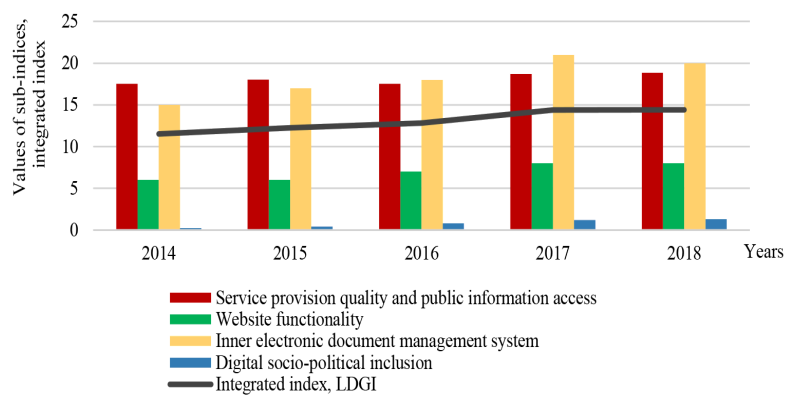

Fig. 2. The results of assessing the state of digitalization of public management and administration on the example of Vinnytsia city united territorial community during 2014-2018 
Structural-logical scheme of calculation of the integrated index of digitalization of public management and administration on the example of Vinnytsia city united territorial community 2014-2018

\begin{tabular}{|c|c|c|c|c|c|c|c|c|}
\hline \multirow{2}{*}{ No. } & \multirow{2}{*}{\multicolumn{2}{|c|}{ Indicators, criteria groups, local criteria }} & \multirow{3}{*}{$\begin{array}{l}\text { Coefficients } \\
\beta_{11}=0.357 \\
\end{array}$} & \multicolumn{5}{|c|}{ Values by years } \\
\hline & & & & \multirow{2}{*}{$\begin{array}{c}2014 \\
23 \\
\end{array}$} & \multirow{2}{*}{$\begin{array}{c}2015 \\
23 \\
\end{array}$} & \multirow{2}{*}{$\begin{array}{c}2016 \\
23\end{array}$} & \multirow{2}{*}{$\begin{array}{c}2017 \\
25\end{array}$} & \multirow{2}{*}{$\begin{array}{c}2018 \\
25\end{array}$} \\
\hline 1 & Quality of service provision and & Information access, $b_{11}$ & & & & & & \\
\hline & public information access & Administrative services, $\beta_{12}$ & $\beta_{12}=0.090$ & 21 & 21 & 21 & 21 & 21 \\
\hline & & Public feedback, $b_{13}$ & $\beta_{13}=0.160$ & 9 & 12 & 9 & 11 & 12 \\
\hline & & Public information access, $\beta_{14}$ & $\beta_{14}=0.260$ & 18 & 18 & 18 & 18 & 18 \\
\hline & & $\begin{array}{l}\text { Organization of activities of administrative } \\
\text { services centres, } b_{15}\end{array}$ & $\beta_{15}=0.120$ & 11 & 11 & 11 & 12 & 12 \\
\hline & & $S_{q}$ & $\lambda_{s}=0.43$ & 17.54 & 18.02 & 17.54 & 18.70 & 18.86 \\
\hline 2 & Website functionality & $W_{f}$ & $\lambda_{w}=0.20$ & 6 & 6 & 7 & 8 & 8 \\
\hline 3 & $\begin{array}{l}\text { Internal electronic document } \\
\text { management system }\end{array}$ & $I_{d}$ & $\lambda_{i}=0.17$ & 15 & 17 & 18 & 21 & 20 \\
\hline \multirow[t]{4}{*}{4} & \multirow[t]{4}{*}{ Digital socio-political inclusion } & Feedback tools, $b_{41}$ & $\beta_{41}=0.285$ & 4 & 5 & 6 & 7 & 8 \\
\hline & & Implementation of e-petitions, $b_{42}$ & $\beta_{42}=0.325$ & 0 & 2 & 5 & 6 & 7 \\
\hline & & Community initiatives budget, $b_{43}$ & $\beta_{43}=0.39$ & 0 & 0 & 2 & 5 & 5 \\
\hline & & $D_{e f}$ & $\lambda_{d}=0.20$ & 1.14 & 2.08 & 4.12 & 5.90 & 6.51 \\
\hline \multicolumn{4}{|c|}{ Integrated index $L D G I$} & 11.52 & 12.25 & 12.83 & 14.39 & 14.41 \\
\hline
\end{tabular}

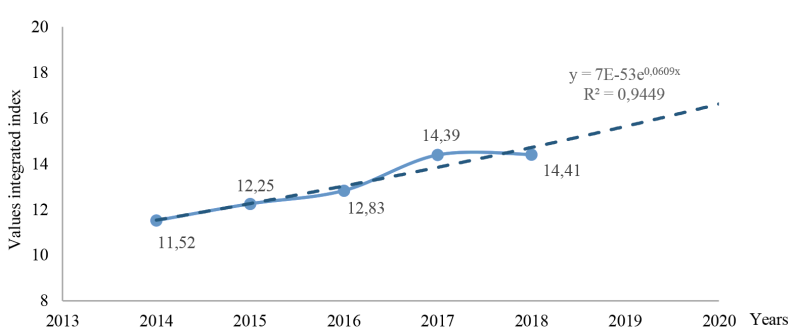

Fig. 3. The results of forecasting the integrated index of digitalization of public management and administration on the example of Vinnytsia city united territorial community for 2019-2020

used. The dynamics of the level of digitalization of public management and administration of Vinnytsia city united territorial community will be positive (Fig. 3).

So, the approbation of the authors' model demonstrated that it can be used to assess digitalization of public management and administration at the level of territorial communities. Due to the proposed methodology it is possible to carry out a systematic analysis of the problem, its structuring and presentation in the form of a hierarchy; to form a database of the actual state through the calculation of both the integrated index and its structural components; to work with a variety of statistical information; along with a wide range of quantitative characteristics of the state of digitalization of public management and administration, to take into account the qualitative aspects of the problem that do not have a direct numerical expression.

Conclusions. The article analyses the evolution of management model in the public sector and investigates the multi-vector process of digital governance formation in Ukrainian realities.

The authors prove that assessing of digital governance will increase the reliability of the process of development and decision-making in the management of complex multi-level socioeconomic systems, providing an opportunity to assess different strategies of digital transformation.

In the article it is substantiated that the conceptual approaches of global indices to assessing the development of digital society and digital governance will be useful for the development of analytical tools adapted to the specifics of the content of digital development of Ukraine at the local level.

Proceeding from the necessary precondition of reliability of diagnostic conclusions, the authors proposed their own model adapted to the specifics of the level of territorial com- munities in order to provide full understanding of the level of digitalization of public management and administration at the local level. The proposed mathematical model for assessing digitalization of public management and administration at the level of territorial communities is open for logical changes and additions. In order to test the developed methodology, the assessment of digitalization of public management and administration was carried out on the example of Vinnytsia city united territorial community during 2014-2018.

\section{References.}

1. Cabinet of Ministers of Ukraine (2018). On Approval of the Concept for the Development of the Digital Economy and Society of Ukraine for 2018-2020 and approval of the plan of measures for its implementation. Order. Retrieved from https://zakon.rada.gov.ua/laws/show/67-2018-\%D1\%80\#n13.

2. Cabinet of Ministers of Ukraine (2019). Issues on digital development. Order. Retrieved from https://zakon.rada.gov. ua/laws/show/56-2019-\%D0\%BF.

3. Dunleavy, P., \& Margetts, H. (2015). Design Principles for Essentially Digital Governance. $111^{\text {th }}$ Annual Meeting of the American Political Science Association. San Francisco. Retrieved from https://www.researchgate.net/publication/282867465 Design Principles for Essentially Digital Governance.

4. Corydon, B., Ganesan, V., \& Lundqvist, M. (2016). Transforming government through digitization. Retrieved from https://www.mckinsey.com/industries/public-sector/our-insights/transforming-government-through-digitization/.

5. United Nations (2018). E-Government Development Index. Retrieved from https://publicadministration.un.org/ egovkb/en-us/Data/CountryInformation/id/180-Ukraine. 6. United Nations (2018). E-government Survey. Retrieved from https://www.unescap.org/sites/default/ files/E-Government\%20Survey\%202018 FINAL.pdf.

7. United Nations (2018). E-Participation Index. Retrieved from https://publicadministration.un.org/egovkb/en-us/About/ Overview/E-Participation-Index10.

8. Kuybida, V. S., Karpenko, O. V., \& Ryzhenko, O. V. (2019). Information and communication executive power. Kyiv: TSP "Komprynt".

9. Karpenko, O. (2017). Digital Governance: implementation imperatives in Ukraine. Current problems of public administration, 3(71), 57-61.

10. Yaskevych, A. I. (2018). Monitoring of implementation of e-governance tools in local government of the largest cities of 
Ukraine. Vinnytsia: HO "Podilska ahentsiia rehionalnoho rozvytku".

11. Digital Agenda of Ukraine - 2020 (Digital Agenda 2020)/ Conceptual Background (Version 1.0) (2016). Hiteh-offic. 12. Nikolina, I. I., Nikolina, I. I., \& Yanush, M. P. (2019). Peculiarities of mplementationad perspectives of Mobile ID in Ukraine. Komp'yuterno-integrirovannyye tekhnologii: obrazovaniye, nauka, proizvodstvo, 34, 91-95.

13. Karpenko, O., Levchenko, O., \& Sakalosh, S. (2019). Participatory transformations at local level: electronic and digital democracy. Current problems of public administration, 1(77), 111115. https://doi.org/10.35432/1993-8330appa1772019170439.

14. Hermann, M., Pentek, T., \& Otto, B. (2015). Design Principles for Industrie 4.0 Scenarios: A Literature Review. Technische Universitat Dortmund. Retrieved from https://pdfs.semanticscholar.org/069c/d102faebef48fbb7b531311e0127652d926e.pdf. 15. Wray, S. (2019). Multi-channel citizen engagement and XaaS: Gartner pinpoints next govtech trends. Retrieved from https://www.smartcitiesworld.net/news/news/multi-channel-citizen-engagement-and-xaas-gartner-pinpoints-nextgovtech-trends-4682.

16. Urintsov, A. I., Dick, V. V., Kameneva, N. O., \& Makarenkova, K. V. (2014). Information society as an environment for creating new knowledge. Naukovyi Visnyk Natsionalnoho Hirnychoho Universytetu, (4), 113-120.

\section{Оцінювання цифровізації публічного управління та адміністрування на рівні територіальних громад}

\section{I. І. Ніколіна ${ }^{1}$, І. О. Гулівата ${ }^{1}$, Л. П. Гусак ${ }^{1}$, Л. М. Радзіховська ${ }^{1}$, I. І. Ніколіна ${ }^{2}$}

1 - Вінницький торговельно-економічний інститут КНТЕУ, м. Вінниця, Україна, e-mail: nikira1205@gmail.com 2 - Вінницький державний педагогічний університет імені Михайла Коцюбинського, м. Вінниця, Україна

Мета. Обгрунтувати методологію застосування математичних методів до оцінки цифровізації публічного управління та адміністрування, апробація авторської моделі такого оцінювання на рівні територіальних громад.

Методика. Застосовані теоретичні (аналіз, синтез, систематизація, узагальнення) та емпіричні (спостереження, математико-статистичний аналіз, моделювання, порівняння) методи дослідження.

Результати. Аналіз процесу становлення цифрового врядування в українських реаліях, дослідження концептуальних підходів глобальних індексів щодо оцінки розвитку цифрового суспільства та цифрового врядування дозволили здійснити розробку аналітичного інструментарію, адаптованого до специфіки контенту цифрового розвитку на місцевому рівні. Авторами доведено, що оцінювання цифрового врядування підвищить надійність процесу розробки та прийняття рішень в управлінні складними багаторівневими соціально-економічними системами, забезпечуючи можливість оцінки різних стратегій цифрової трансформації. Автори запропонували власну апробовану модель з метою комплексного розуміння цифровізації публічного управління та адміністрування на місцевому рівні. Доведено, що авторська методика дозволяє провести системний аналіз стану цифровізації публічного управління та адміністрування на рівні територіальних громад.

Наукова новизна. Полягає в постановці й вирішенні проблеми вдосконалення методологічного інструментарію оцінювання цифровізації публічного управління та адміністрування на рівні територіальних громад шляхом використання чотирьох індикаторів інтегрованого індексу: субіндексів якості надання послуг та доступу до публічної інформації, функціональності веб-сайту, цифрової соці- ально-політичної інклюзії, системи внутрішнього електронного документообігу органів місцевого самоврядування.

Практична значимість. Продемонстровано практичний приклад реалізації моделі оцінки цифровізації публічного управління та адміністрування на рівні територіальних громад з метою комплексного розуміння рівня цифрової трансформації на місцевому рівні.

Ключові слова: иифрова трансформація, публічне управління, адміністрування, модель, територіальна громада

\section{Оценивание цифровизации публичного управления и администрирования на уровне территориальных общин}

\section{И. И. Николина ${ }^{1}$, И. А. Гуливата ${ }^{1}$, Л. П. Гусак ${ }^{1}$, Л. Н. Радзиховская ${ }^{1}$, И. И. Николина ${ }^{2}$}

1 - Винницкий торгово-экономический институт КНТЭУ, г. Винница, Украина, e-mail: nikira1205@gmail.com 2 - Винницкий государственный педагогический университет имени Михаила Коцюбинского, г. Винница, Украина

Цель. Обосновать методологию применения математических методов к оцениванию цифровизации публичного управления и администрирования, апробация авторской модели такого оценивания на уровне территориальных общин.

Методика. Применены теоретические (анализ, синтез, систематизация, обобщение) и эмпирические (наблюдение, математико-статистический анализ, моделирование, сравнение) методы исследования.

Результаты. Анализ процесса становления цифрового управления в украинских реалиях, исследования концептуальных подходов глобальных индексов в оценке развития цифрового общества и цифрового управления позволили осуществить разработку аналитического инструментария, адаптированного к специфике контента цифрового развития на местном уровне. Авторами доказано, что оценка цифрового управления повысит надежность процесса разработки и принятия решений в управлении сложными многоуровневыми социально-экономическими системами, обеспечивая возможность оценки различных стратегий цифровой трансформации. Авторы предложили собственную апробированную модель с целью комплексного понимания уровня цифровизации публичного управления и администрирования на местном уровне. Доказано, что авторская методика позволяет провести системный анализ цифровизации публичного управления и администрирования на уровне территориальных общин.

Научная новизна. Заключается в постановке и решении проблемы совершенствования методологического инструментария оценивания цифровизации публичного управления и администрирования на уровне территориальных общин путем использования четырех индикаторов интегрированного индекса: субиндексов качества предоставления услуг доступа к публичной информации, функциональности сайта, цифровой социально-политической инклюзии, системы внутреннего электронного документооборота органов местного самоуправления.

Практическая значимость. Продемонстрирован практический пример реализации модели оценивания цифровизации публичного управления и администрирования на уровне территориальных общин с целью комплексного понимания уровня цифровой трансформации на местном уровне.

Ключевые слова: цифровая трансформация, публичное управление, администрирование, модель, территориальная община

Recommended for publication by A. M. Tanasiychuk, Doctor of Economic Sciences. The manuscript was submitted 01.04.20. 